\title{
RADIOCARBON AND THERMOLUMINESCENCE DATING OF PREHISTORIC SITES IN HUNGARY AND YUGOSLAVIA
}

\author{
LÁZÁR BENKÖ*, FERENC HORVÁTH**, NADA HORVATINČIĆ ${ }^{\dagger}$ \\ and \\ BOGOMIL OBELIC ${ }^{\dagger}$
}

\begin{abstract}
Direct dating by simultaneous independent physical methods is of particular interest to prehistoric archaeology in central Europe. Radiocarbon and thermoluminescence measurements were made to date two tell settlements in the Carpathian Basin: the Late Neolithic site at Gorzsa (southeast Hungary) and the Eneolithic site of Vučedol (east Croatia, Yugoslavia). Samples from Gorzsa span from the Szakalhát to the Proto-Tiszapolgár periods, while most important cultural layers from the Vučedol site belong to the Baden, Kostolac, and Vučedol cultures. By including some of our earlier dates from the Tiszapolgar-Basatanya Copper Age site, a chronological framework, spanning the period from Late Neolithic to Early Bronze Age can be established. The quartz inclusion technique was used for TL dating of pottery. Beta and gamma dose rates were determined by TL dosimetry. Allowances were made for supralinearity, water content, and beta attenuation in quartz grains. The TL ages range from 4900 to $4300 \mathrm{BC}$ ànd 3600 to $2900 \mathrm{BC}$, for the Gorzsa and Vučedol sites, respectivety.
\end{abstract}

\section{INTRODUCTION}

In spite of considerable progress in archaeological methods and related analytical techniques, we do not have a reliable prehistoric chronology. The lack of a solid chronological framework is particularly pronounced for the Neolithic and Copper Age cultures of the Carpathian Basin. Moreover, radiocarbon dates are scanty and the calibrated values are sometimes regarded as inconsistent with archaeological expectations, such expectations being conventionally based on typological and stratigraphic methods of dating.

This paper describes results obtained by thermoluminescence (TL), an independent method of absolute dating. To check the validity of the dates, parallel radiocarbon measurements were made as well. TL dating of pottery samples was done at the Institute of Isotopes, Budapest, and charcoal and bone samples were ${ }^{14} \mathrm{C}$ dated at the Ruđer Bošković Institute, Zagreb. Figure 1 shows the locations of the investigated sites.

\section{THERMOLUMINESCENCE DATING}

Thermoluminescence plays an important role in direct dating of pottery. While ${ }^{14} \mathrm{C}$ samples may be earlier than associated archaeological sites, TL dating gives, in principle, the actual date of firing. TL dating also has advantages over other dating techniques for excavations deficient in suitable organic material. In any case, it is of particular interdisciplinary interest to cross-check ${ }^{14} \mathrm{C}$ and TL dates.

Thermoluminescence in ceramics derives from ionizing radiation emitted by radioactive isotopes naturally present in clay and the surrounding burial soil. Archaeologically acquired TL is a measure of the total natural

\footnotetext{
* Institute of Isotopes of the Hungarian Academy of Sciences, POB 77, 1525 Budapest, Hungary

** Móra Ferenc Museum, POB 474, 6701 Szeged, Hungary

† Ruđer Bošković Institute, POB 1060, 41001 Zagreb, Yugoslavia
} 


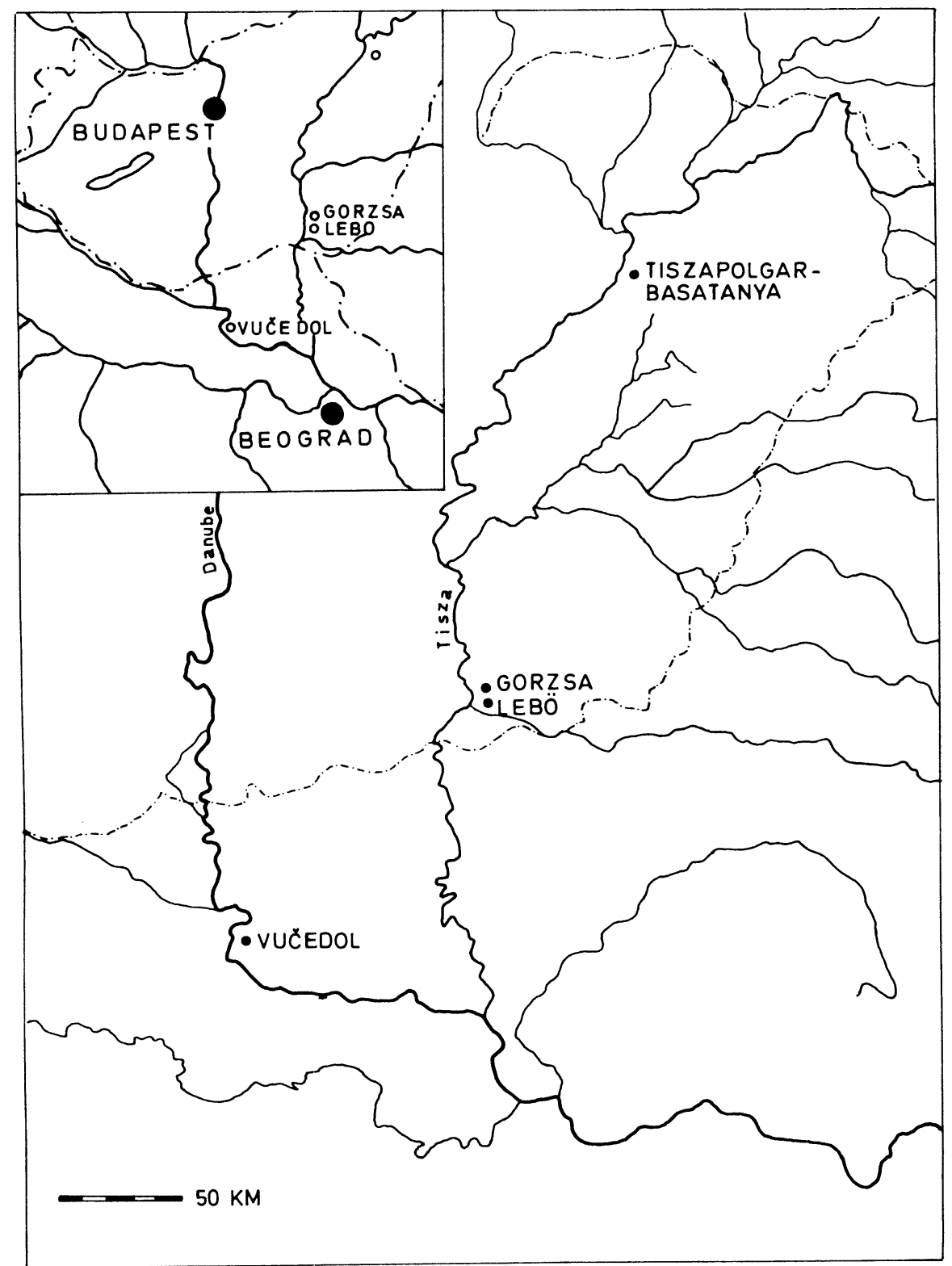

Fig 1. Prehistoric sites in the Carpathian Basin, dated by ${ }^{14} \mathrm{C}$ and TL 
dose $\left(D_{n}\right)$ absorbed by the sample during its past. To calculate the age, the corresponding natural dose-rate $\dot{D}_{n}$ is to be determined as well. In its basic form, the TL age relation is given by

$$
\mathrm{A}=\mathrm{D}_{\mathrm{n}} / \dot{\mathrm{D}}_{\mathrm{n}}
$$

The assessment of $D_{n}$ requires laboratory irradiation with known doses from calibrated radioisotope sources, while the components of natural doserate (annual dose) can be determined analytically or by TL dosimetry. However, in practice, accurate TL dates are not easily obtained because of inherent complexities of TL phenomena, uncertainties in dosimetry, and environmental conditions.

Aitken (1985) described several techniques of TL dating. In our studies, we used the quartz inclusion technique (Fleming, 1970) and adapted it to specific conditions, such as the extremely low occurrence of quartz grains in most of the pottery originating from prehistoric sites on the Hungarian Plain (Benkö, 1983).

The advantages of this technique are the elimination of difficult alpha dosimetry and resistance of quartz to anomalous fading. In our procedure, the sherds are crushed to fragments of $\mathrm{ca} 0.5 \mathrm{~cm}$, divided into small portions and repeatedly treated in $\mathrm{HCl}$ and $\mathrm{HF}$ in an ultrasonic bath. The clay matrix is successively eliminated by rinsing in distilled water. Subsequent to the decomposition of the fragments, residual grains are etched in HF for one hour. After sieving, the quartz fraction, from 0.09 to $0.125 \mathrm{~mm}$, is used for TL measurements. Alternatively, we also use magnetic separation.

The TL measurements were made with a photon counting apparatus (Daybreak System). The glow curves were recorded by a multichannel analyzer and then evaluated numerically.

Since the sensitivity of the quartz is affected by its previous thermal and dose history, several aliquots are needed to determine $D_{n}$. The natural TL is derived from the first aliquot, while the rest receive known artificial doses in addition to the natural dose before measuring (Fig 2). This enables us to construct a TL growth for unheated samples.

For laboratory irradiations, a calibrated ${ }^{90} \mathrm{Sr}$ source of $2 \mathrm{GBq}$ activity was used. The dose rate delivered per minute to quartz is ca $2.5 \mathrm{~Gy}$. In our typical prehistoric quartz samples the natural dose amounted to 20 Gy which required exposure times of 3 to $15 \mathrm{~min}$.

In our standard glow-out technique, $2 \mathrm{mg}$ of quartz is uniformly spread on a stainless-steel cup and heated to $450^{\circ} \mathrm{C}$ at a rate of $20^{\circ} \mathrm{C} / \mathrm{s}$. To eliminate the TL stored in quartz at lower temperatures because of possible fading over time, it was preheated to ca $320^{\circ} \mathrm{C}$ for $30 \mathrm{sec}$. The appropriate temperature interval (ranging from 360 to $390^{\circ} \mathrm{C}$ ) was selected by doing the plateau test, in which the shape of the natural glow curve is compared with the (natural + artificial) glow curve. The natural dose was corrected for supralinearity, by determining the second-glow growth characteristic at a lower dose of quartz that has already been heated.

Both contributions to the annual dose ( $\gamma$ from the burial soil and $\beta$ from the pottery matrix) were measured by high sensitivity $\mathrm{CaSO}_{4}$ : Dy TL phosphor. Copper capsules, $1 \mathrm{~mm}$ thick, filled with $\mathrm{CaSO}_{4}$ : Dy were placed in the soil in as natural a setting as possible. Capsules were left buried for a year in 


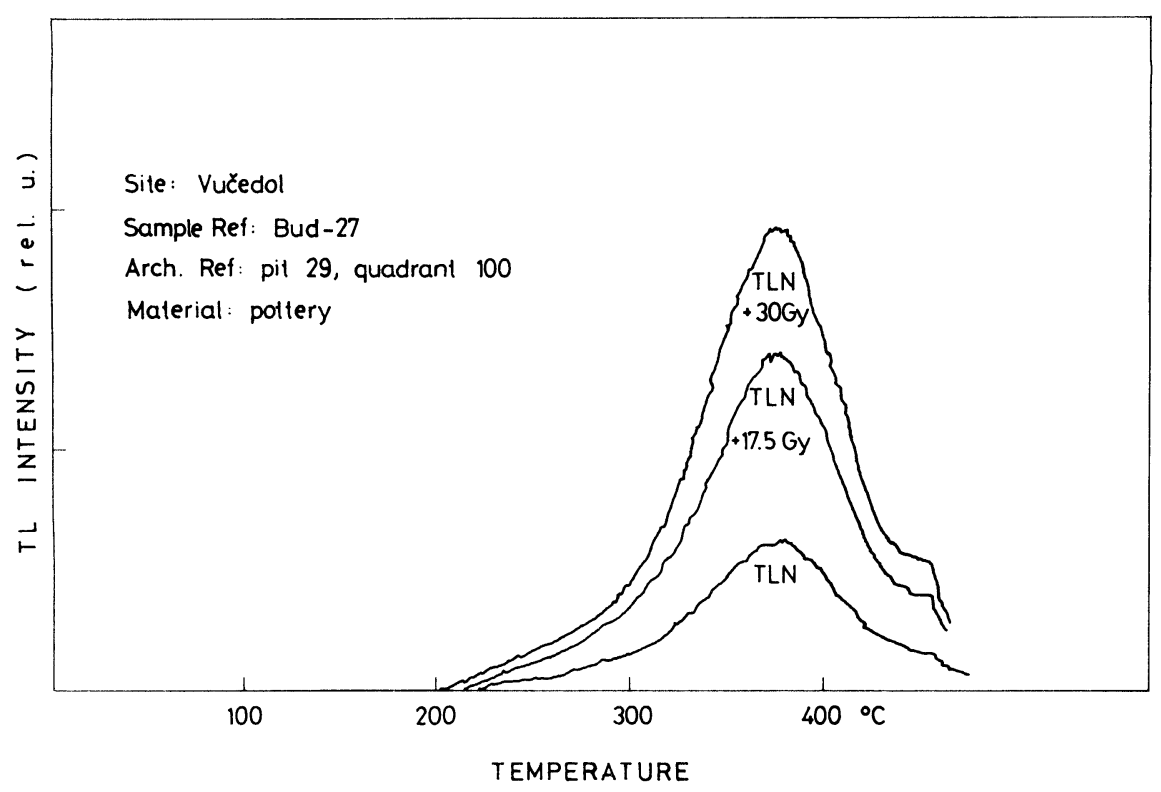

Fig 2. Typical glow curves (high temperature regions) for the additive technique (TLN = TL corresponding to natural, ie, archaeological dose)

order to even out seasonal fluctuations of $\gamma$ dose-rate. Corrections were also made for attenuation and energy response.

From the point of view of uncertainties relating to the retrospective dose rate assessment at the Tiszapolgár-Basatanya site, the graves and vessels were carefully selected with regard to minimizing the disturbing effects from surrounding finds. The $\gamma$ dose-rate was measured for three years by TLD probes at several points and depths of undisturbed soil (Fig 3).

To evaluate the $\beta$ dose-rate, the phosphor is contained in a polycarbonate tube which is inserted into a plastic container filled with the powdered clay sample. By shielding the container against external radiation, after storage of several months, the TL emitted by the phosphor was measured (Valladas \& Valladas, 1983).

In determining the actual values of $\beta$ dose-rate, adequate allowances were made for water content (Zimmerman, 1971) and $\beta$ attenuation in quartz grains (Mejdahl, 1979).

We have developed a new and rapid technique for obtaining the $\beta$ doserate. Our preliminary results show that doses as low as $50 \mathrm{nGy}$ can be evaluated under specific experimental conditions. One hundred $\mathrm{mg}$ of $\mathrm{CaSO}_{4}$ : Dy is spread on the heating plate of the TL apparatus and placed in an iron shield, $20 \mathrm{~cm}$ thick, with $14.5 \mathrm{nGy} / \mathrm{h}$ background. Replacing the PM tube with a container filled with $10 \mathrm{~g}$ of powdered clay, on-plate exposures are made overnight (Fig 4). The same phosphor can be re-used with no loss of sensitivity, enabling us to eliminate sample-to-sample variations when different pottery and calibrations, using $\mathrm{K}_{2} \mathrm{CO}_{3}$, and NBL reference standards 


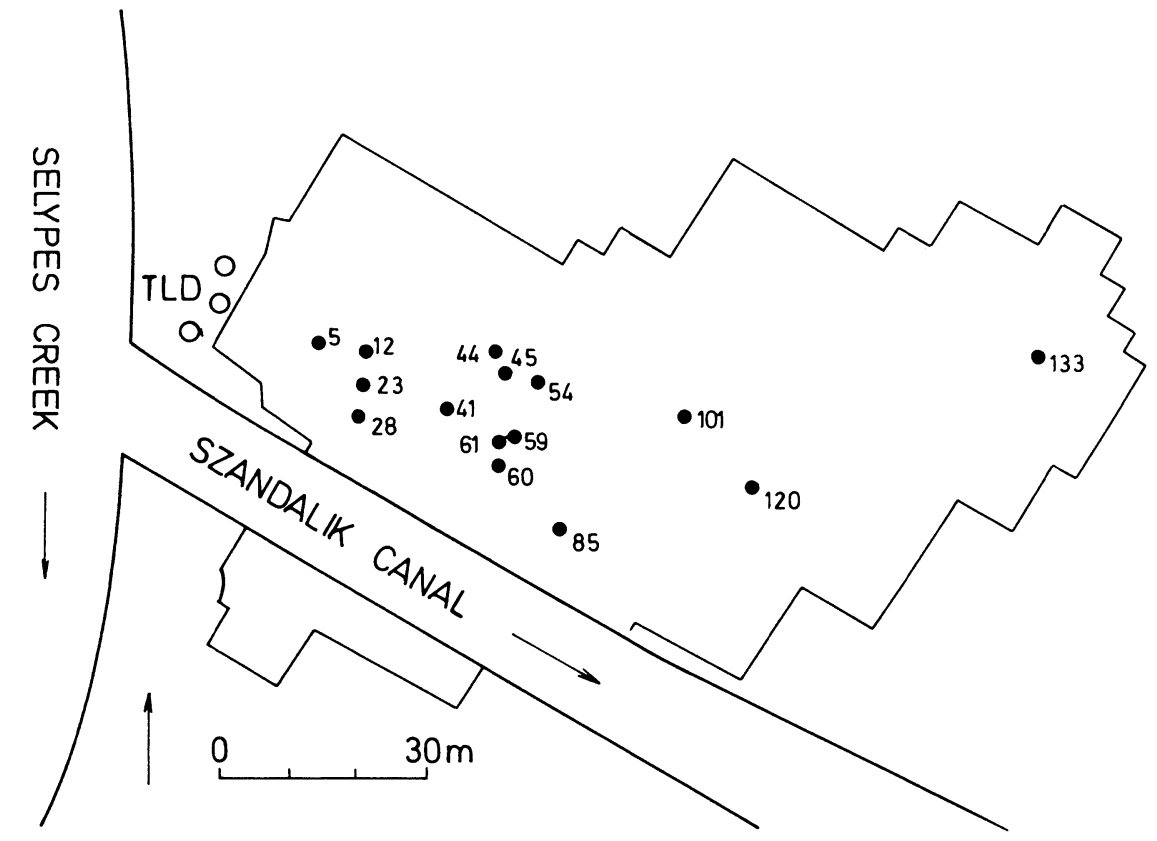

Fig 3. The Copper Age cemetery of Tiszapolgár-Basatanya. Graves investigated by TL are indicated by dots. TLD refers to the location of probes for measuring the $\gamma$ dose-rate

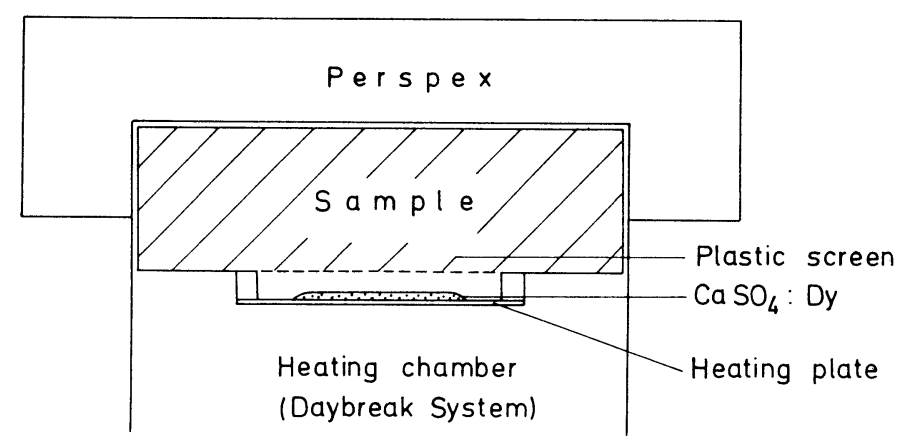

Fig 4. On-plate measurement of $\beta$ dose-rate. The glow oven and TLD assembly are placed in an iron shield, $20 \mathrm{~cm}$ thick. Phosphor thickness is ca $60 \mathrm{mg} \mathrm{cm}^{-2}$. Phosphor to sample distance is $2.5 \mathrm{~mm}$. A plastic screen, $20 \mathrm{mg} \mathrm{cm}^{-2}$ thick, shields the phosphor from $\alpha$ particles. 
(104-A, 109-A), are studied. The average value of the ratios between phosphor dose and internal sample dose was found to be 0.23 , the isotope dependence is $< \pm 5 \%$. For brick samples which were studied in an interlaboratory comparison (Haskell, 1983), the $\beta$ dose-rates are within $\pm 7 \%$ limits of those reported as mean values. A test program with a number of pottery samples is currently in progress. Typical glow curves can be seen in Figure 5.

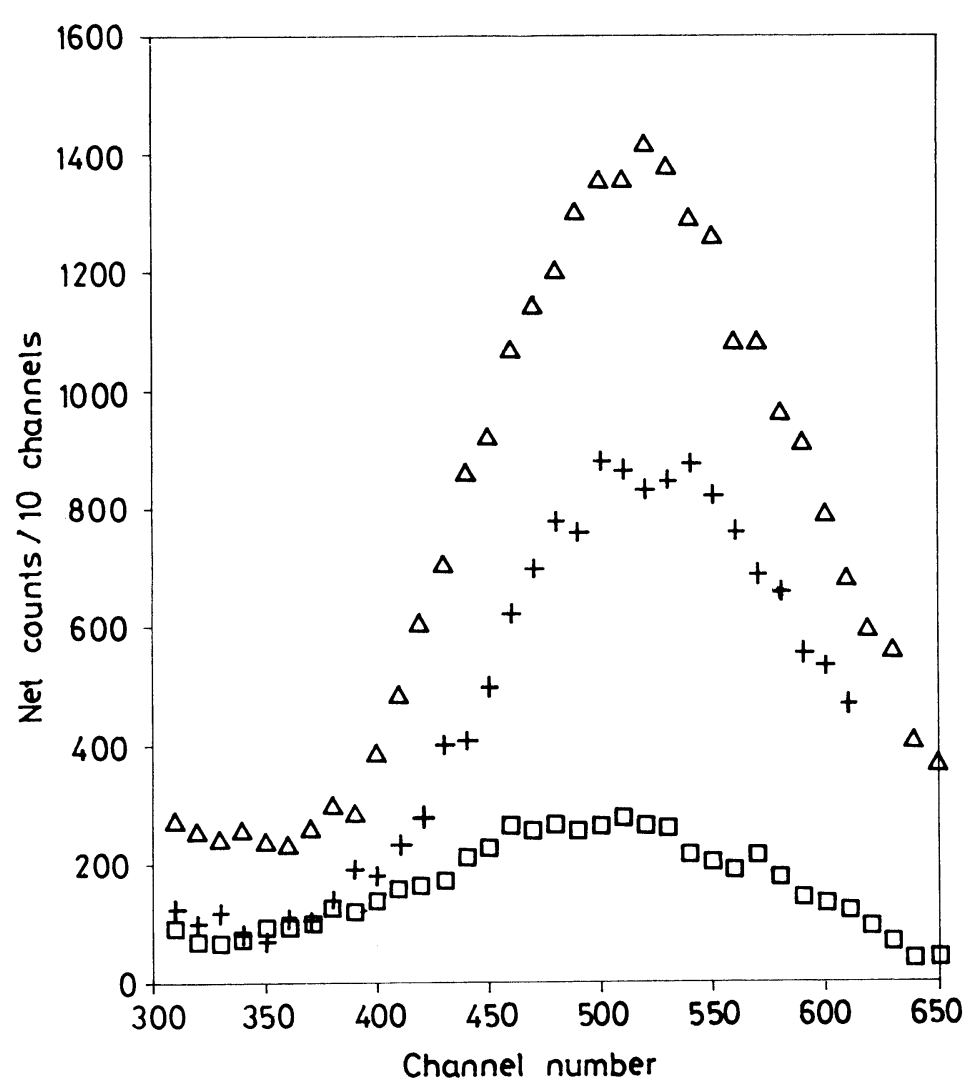

口 Background, $17.37 \mathrm{~h} \quad \Delta$ Potassium carbonate, ih +Brick sample $17.37 \mathrm{~h}$

Fig 5. TL response of $\mathrm{CaSO}_{4}$ : Dy to extra low doses delivered by natural samples, as measured in an iron shield, $20 \mathrm{~cm}$ thick, for the direct on-plate assessment of $\beta$ dose-rate. Optical filter: MTO DH $485 \mathrm{~b}, 61 \mathrm{~mm}$ diameter, $3 \mathrm{~mm}$ thick. Counts/hr from 410 to 610 channels $\left(180-268^{\circ} \mathrm{C}\right)$ : background $250, \mathrm{~K}_{2} \mathrm{CO}_{3} 21483$, brick sample (J) 764 (1.62 $\pm 0.11 \mathrm{mGy} / \mathrm{yr}$, Haskell, 1983) 


\section{RADIOCARBON DATING}

Most of the archaeological samples used for ${ }^{14} \mathrm{C}$ dating at the Ruder Bošković Institute were charcoal. Three bone samples were also analyzed, but the results are less reliable than charcoal samples because of the possibility of contamination of bones (Horvatinčić et al, 1973). Charcoal is pretreated by boiling in $4 \% \mathrm{HCl}$ and $4 \%$ solution of $\mathrm{NaOH}$. Collagen fraction from the bone was separated following Longin (1971). Further processing includes combustion of samples, catalytic hydrogenation of $\mathrm{CO}_{2}$ to $\mathrm{CH}_{4}$, and measurement in a proportional counter for 24 hours. Results are given in years BP, based on the Libby half-life 5568 years. No ${ }^{13} \mathrm{C}$ measurements were performed, but $\delta^{13} \mathrm{C}$ correction was made according to Stuiver and Polach (1977). All the results are dendrochronologically corrected according to Stuiver and Reimer (1986).

The ${ }^{14} \mathrm{C}$ dating method and related procedures were previously published (Srdoč, Sliepčević \& Breyer, 1971; Srdoč, Breyer \& Sliepčević, 1971).

${ }^{14} \mathrm{C}$ dates for the Vučedol site were also discussed (Horvatinčić et al, 1988).

For comparison with TL dates from the Tiszapolgár-Basatanya site, earlier ${ }^{14} \mathrm{C}$ dates, produced with bone samples by the Institute of Nuclear Research, Debrecen, Hungary, are relevant (Csongor et al, 1983; Benkö \& Bognár-Kutzián, 1988; Bognár-Kutzián \& Csongor, 1987).

\section{THE ARCHAEOLOGICAL SITES}

Gorzsa. The Late Neolithic of southeast Hungary can be characterized by the Tisza culture and the succeeding period of the Proto-Tiszapolgár group, forming a transition to the Early Copper Age. The Tápé-Lebö site probably dates from the second part of Middle Neolithic and is considered to be contemporary with the Vinča $\mathrm{Bl}$ phase. The Gorzsa settlement embraces the late period of the Tisza culture and it corresponds to the Vinča C-D phases.

Pottery and charcoal samples were taken from the tell settlements, Tápé-Lebö A and Gorzsa. Each is multi-layered and was inhabited over a long period of time. Thus, the stratigraphic sequence provides a relative chronological scale. Gorzsa levels $\mathrm{A}, \mathrm{Al}, \mathrm{B}, \mathrm{C}, \mathrm{Cl}$, and D correspond to six distinct occupational phases (Horváth, 1982).

Tiszapolgár-Basatanya. This site is in eastern Hungary, along the upper course of the Tisza River. During the excavations from 1950 to 1954, 155 graves were found in $3225 \mathrm{~m}^{2}$ (Bognár-Kutzián, 1963). The 25 Copper Age vessels analyzed by TL came from 15 graves (Fig 3). Seven graves $(5,12,23$, $28,54,60,61)$ can be assigned to the early phase while the rest $(41,44,59$, $85,101,120)$ represent phase $A$ of the middle period, with the exception of grave 133, which belongs to the late phase B (Bodrogkeresztúr culture). Three vessels were studied from each of graves 12,28 and 120 . Two vessels from each of graves 5, 41, 44 and 54 were also analyzed.

$V u c ̌ e d o l$. Life on this tell lasted over a long period - until Roman occupation. Most layers belong to the Eneolithic, which is represented by the Baden, Kostolac and Vučedol cultures (Neustupný, 1968; Gimbutas, 1980). All ${ }^{14} \mathrm{C}$ and TL samples from pits or graves correspond very precisely to specific cultures. Two samples from the neighboring complex, Vinkovci (Late Vučedol 
TABLE 1

Radiocarbon and TL ages for sites in Yugoslavia: Early Bronze Age (Vinkovci) Middle Copper Age (Vučedol)

\begin{tabular}{|c|c|c|c|c|c|c|}
\hline \multirow[b]{2}{*}{ Site } & \multirow{2}{*}{$\begin{array}{l}\text { Archaeol } \\
\text { phase }\end{array}$} & \multicolumn{3}{|c|}{${ }^{14} \mathrm{C}$ results } & \multicolumn{2}{|c|}{ TL results } \\
\hline & & $\begin{array}{l}\text { Lab } \\
\text { no. }\end{array}$ & $\begin{array}{l}\text { Conventional } \\
{ }^{14} \mathrm{C} \text { age(BP) }\end{array}$ & $\begin{array}{c}\text { Calibrated } \\
\text { age span (BC) }\end{array}$ & $\begin{array}{l}\text { Lab } \\
\text { no. }\end{array}$ & $\begin{array}{l}\text { TL age } \\
\text { (BC) }\end{array}$ \\
\hline \multirow[t]{2}{*}{ Vinkovci } & Late & Z-1817 & $3800 \pm 140$ & 2470-2040 & & \\
\hline & Vučedol & -1818 & $3830 \pm 140$ & $2480-2040$ & & \\
\hline \multirow[t]{17}{*}{ Vučedol } & Vučedol & -1447 & $4290 \pm 120$ & $3040-2700$ & Bud-28 & $2960 \pm 580$ \\
\hline & & -1449 & $4190 \pm 120$ & $2920-2590$ & -61 & $3080 \pm 470$ \\
\hline & & -1453 & $4280 \pm 120$ & $3030-2700$ & & \\
\hline & & -1454 & $4540 \pm 120$ & $3490-3040$ & & \\
\hline & & -1621 & $4310 \pm 100$ & $3040-2780$ & & \\
\hline & & -1622 & $4150 \pm 100$ & $2900-2580$ & & \\
\hline & & -1624 & $4210 \pm 100$ & $2920-2620$ & & \\
\hline & & -1637 & $4320 \pm 100$ & $3040-2790$ & & \\
\hline & & $-1863^{*}$ & $4190 \pm 180$ & $3020-2500$ & & \\
\hline & & $-1865^{*}$ & $4030 \pm 140$ & $2870-2400$ & & \\
\hline & Kostolac & -1820 & $4370 \pm 140$ & $3320-2790$ & & \\
\hline & & -1821 & $4500 \pm 150$ & $3310-2920$ & & \\
\hline & Baden & -1446 & $4540 \pm 130$ & $3500-3040$ & Bud-27 & $3360 \pm 510$ \\
\hline & & -1617 & $4400 \pm 100$ & $3310-2910$ & -62 & $3640 \pm 600$ \\
\hline & & -1618 & $4310 \pm 100$ & $3040-2780$ & -63 & $3200 \pm 490$ \\
\hline & & -1619 & $4410 \pm 100$ & $3320-2920$ & & \\
\hline & & $-1864^{*}$ & $4620 \pm 150$ & $3620-3100$ & & \\
\hline
\end{tabular}

*Bone samples; the other ${ }^{14} \mathrm{C}$ :.11mplin are charcoal

culture), were dated to determine the duration of the Vučedol culture in this area.

The relative chronological sequence of the sites and the results of ${ }^{14} \mathrm{C}$ and TL dating are summarized in Tables 1 and 2.

\section{DISCUSSION AND CONCLUSION}

The investigated sites span a long period from the Late Neolithic (TápéLebö A, Gorzsa) to the Late Copper Age - Early Bronze Age (Vinkovci). The relative chronology of the sites and that of the associated phases, based on conventional archaeological methods, is well supported by ${ }^{14} \mathrm{C}$ dates. The results for Gorzsa are of particular importance because, until now, as few as three ${ }^{14} \mathrm{C}$ dates were known for this site: 
TABLE 2

${ }^{14} \mathrm{C}$ and TL ages for sites in Hungary: Middle and Early Copper Age (Tiszapolgár-Basatanya) - Late Neolithic (Gorzsa, Tápé-Lebö)

\begin{tabular}{|c|c|c|c|c|c|c|}
\hline \multicolumn{3}{|l|}{ Site } & \multicolumn{2}{|c|}{${ }^{14}$ C results* } & \multicolumn{2}{|c|}{ TL results } \\
\hline $\begin{array}{l}\text { Archaeol } \\
\text { phase }\end{array}$ & $\begin{array}{c}\text { Grave } \\
\text { no. }\end{array}$ & Lab no. & $\begin{array}{l}\text { Conventional } \\
{ }^{14} \mathrm{C} \text { age(BP) }\end{array}$ & $\begin{array}{l}\text { Calibrated } \\
\text { age span (BC) }\end{array}$ & Lab no. & $\begin{array}{l}\text { TL age } \\
(\mathrm{BC})\end{array}$ \\
\hline \multicolumn{7}{|c|}{ Tiszapolgár - Basatanya } \\
\hline Middle B & 133 & Deb-441 & $4090 \pm 180$ & $2910-2460$ & Bud-26 & $3230 \pm 800$ \\
\hline Middle A & $\begin{array}{r}101 \\
101 \\
44 \\
44 \\
41 \\
41 \\
120 \\
120 \\
120 \\
85 \\
59\end{array}$ & $\begin{array}{l}-122 \\
-465 \\
-214 \\
-350 \\
-355\end{array}$ & $\begin{array}{l}4850 \pm 150 \\
5020 \pm 170 \\
4980 \pm 140 \\
5010 \pm 180 \\
5220 \pm 220 \\
4240 \pm 180 \\
5210 \pm 170\end{array}$ & $\begin{array}{l}4030-3690 \\
4000-3640 \\
3970-3640 \\
4000-3640 \\
4340-3830 \\
3040-2590 \\
4240-3810\end{array}$ & $\begin{array}{l}-22 \\
-13 \\
-14 \\
-11 \\
-12 \\
-23 \\
-24 \\
-25 \\
-21 \\
-18\end{array}$ & $\begin{array}{l}4110 \pm 600 \\
4040 \pm 770 \\
4080 \pm 530 \\
4100 \pm 620 \\
3380 \pm 520 \\
3840 \pm 760 \\
4170 \pm 510 \\
3550 \pm 540 \\
4360 \pm 590 \\
3800 \pm 520\end{array}$ \\
\hline Early & $\begin{array}{r}23 \\
28 \\
28 \\
28 \\
54 \\
54 \\
5 \\
5 \\
12 \\
12 \\
12 \\
61 \\
60\end{array}$ & $\begin{array}{l}-354 \\
-361 \\
-416 \\
-464\end{array}$ & $\begin{array}{l}5020 \pm 180 \\
5060 \pm 170 \\
5090 \pm 190 \\
5350 \pm 190 \\
5600 \pm 180\end{array}$ & $\begin{array}{l}4000-3640 \\
4030-3690 \\
4220-3700 \\
4360-3990 \\
4710-4250 \\
4470 \pm 4050\end{array}$ & $\begin{array}{r}-6 \\
-8 \\
-9 \\
-10 \\
-16 \\
-17 \\
-1 \\
-2 \\
-3 \\
-4 \\
-5 \\
-20 \\
-19\end{array}$ & $\begin{array}{l}4650 \pm 590 \\
4190 \pm 540 \\
4490 \pm 650 \\
3880 \pm 510 \\
4410 \pm 610 \\
4390 \pm 540 \\
4430 \pm 550 \\
4520 \pm 620 \\
4600 \pm 690 \\
5110 \pm 760 \\
3690 \pm 590 \\
3740 \pm 530 \\
4470 \pm 640\end{array}$ \\
\hline \multicolumn{7}{|l|}{ Gorzsa } \\
\hline $\begin{array}{l}\mathrm{A} \\
\mathrm{C} \\
\mathrm{Cl} \\
\mathrm{D}\end{array}$ & & $\begin{array}{r}Z-2009 \\
-2010 \\
-2011\end{array}$ & $\begin{array}{l}5610 \pm 110 \\
5820 \pm 110 \\
5890 \pm 110\end{array}$ & $\begin{array}{l}4650-4350 \\
4840-4550 \\
4930-4680\end{array}$ & $\begin{array}{l}-59 \\
-58 \\
-57 \\
-56\end{array}$ & $\begin{array}{l}4400 \pm 670 \\
4370 \pm 610 \\
4920 \pm 650 \\
4740 \pm 710\end{array}$ \\
\hline Tápé-Lebö A & & -2007 & $5870 \pm 110$ & $4900-4610$ & & \\
\hline
\end{tabular}

${ }^{* 14} \mathrm{C}$ samples are bone

Gorzsa D Fra-108. $5970 \pm 100$ (Quitta, unpub)

Gorzsa Cl Fra-114. $5910 \pm 100$ (Weninger, unpub)

Gorzsa C Bln-3109. $5640 \pm 60$ (Protsch \& Weninger, 1984).

The present results are in full concordance with the above dates.

As far as the Tiszapolgár-Basatanya cemetery is concerned, archaeological assumptions about its long duration, including a transition period, are also evidenced by ${ }^{14} \mathrm{C}$ dates.

The agreement with relative chronology is less obvious when the sequ- 


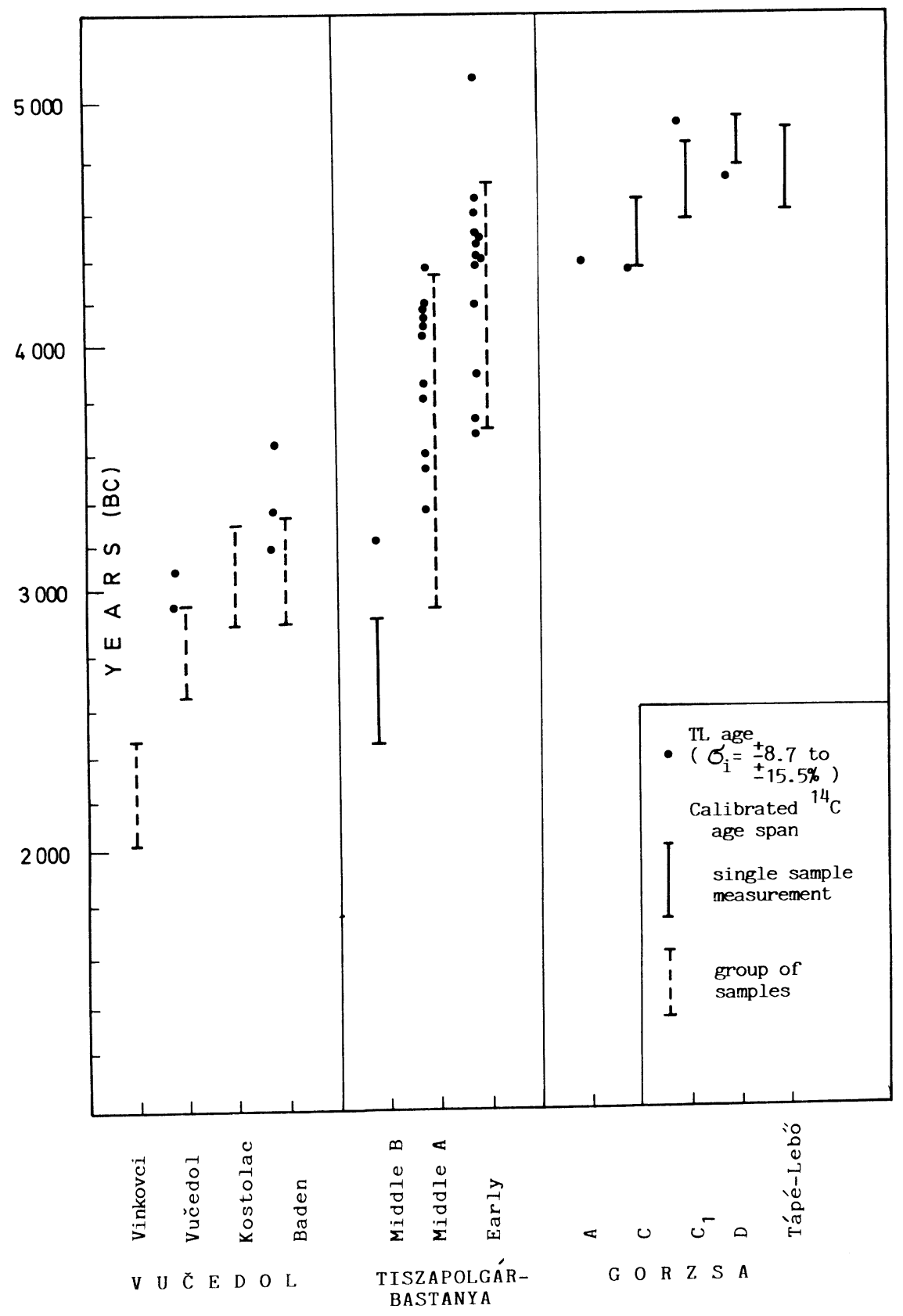

Fig 6. Comparison of TL and calibrated ${ }^{14} \mathrm{C}$ dates 
ence of TL dates is considered. Because of the possibility of error sources which may affect the stored TL information in the pottery and the dose rate, it is unlikely that the present accuracy will ever be improved beyond $\pm 5 \%$ of the age.

Calibrated ${ }^{14} \mathrm{C}$ dates should be considered for a realistic comparison of ${ }^{14} \mathrm{C}$ and TL dates (Fig 6). A satisfactory correlation can be observed between the TL and the corresponding calibrated dates, which validates the TL methodology and ${ }^{14} \mathrm{C}$ calibration.

\section{REFERENCES}

Aitken, M J, 1985, Thermoluminescence dating: London, Academic Press.

Benkö, L, 1983, TL properties of individual quartz grains: PACT, v 9, p 175-181.

Benkö, L and Bognár-Kutzián, I, 1988, Investigation of two Copper Age cultures by means of TL dating: Nuclear Tracks, v 14, p 287-294.

Bognár-Kutzián, I, 1963, The Copper Age cemetery of Tiszapolgár-Basatanya: Budapest, Hungarian Acad Sci.

Bognár-Kutzián, I and Csongor, É, 1987, New results of radiocarbon dating of archaeological finds in Hungary, in Pécsi, M and Kordos, L, eds, Holocene environment in Hungary, INQUA cong, 12th, Proc, Ottawa, Canada: Geog Research Inst, Hungarian Acad Sci.

Csongor, É, Bognár-Kutzián, I, Szabó, I and Hertelendi, E, 1983, Radiocarbon dating of Holocene bone samples in Hungary: PACT, v 8, p 385-390.

Fleming, S J, 1970, Thermoluminescence dating: refinement of the quartz inclusion method: Archaeometry, v 12, p 133-147.

Gimbutas, M, 1980, The Kurgan wave (c 3400-3200 BC) into Europe and the following transformation of culture: Jour Indoeuropean Studies, v 8, 273-315.

Haskell, E H, 1983, Beta dose-rate determination: preliminary results from an interlaboratory calibration of techniques: PACT, $v$ 9, p 77-85.

Horváth, F, 1982, The Late Neolithic stratum of the Gorzsa tell: Archeologiai Értesítö (Budapest), v 109, p 201-222.

Horvatinčić, N, Obelić, B, Srdoč, D, Durman, A, Benkö, L and Sliepčević, A, in press, Radiocarbon and TL dating of the Eneolithic site Vučedol in East Croatia, Yugoslavia, in Internatl symposium, Archaeology and ${ }^{14} \mathrm{C}$, 2nd, Proc: PACT.

Horvatinčić, N, Srdoč, D, Obelić, B and Sliepčević, A, 1973, Radiocarbon dating of fossil bones; development of a new technique for sample processing, in Mook, W G and Waterbolk, H T, eds, Internatl symposium, ${ }^{4} \mathrm{C}$ and Archaeology, lst, Proc: PACT, v 8, p 377-384.

Longin, R, 1971, New method of collagen extraction for radiocarbon dating: Nature, $v 230, p$ 231-242.

Mejdahl, v, 1979, Thermoluminescence dating: beta-dose attenuation in quartz grains: Archaeometry, v 21, p 61-73.

Neustupný, E 1968, Absolute chronology of the Neolithic and Eneolithic periods in central and south-east Europe: Slovenska archeol, v XVI-1, p 19-60.

Protsch, R and Weninger, B, 1984, Frankfurt radiocarbon dates I: Radiocarbon, v 26, no. 2, p 185-195.

Srdoč, D, Breyer, B and Sliepčević, A 1971, Ruđer Bošković radiocarbon measurements I: Radiocarbon, $v 13$, no. 1, p 135-140.

Srdoč, D, Sliepčević, A and Breyer, B 1971, Radiocarbon dating of archaeologic samples of biological origin: Rad, Yugoslavian Acad Sci \& Arts, v 349, p 109-157. Stuiver, M and Polach, H A, 1977, Discussion: Reporting of ${ }^{14} \mathrm{C}$ data: Radiocarbon v 19, no.
3, p 355-363.

Stuiver, M and Reimer, P J, 1986, A computer program for radiocarbon age calibration, in Stuiver, $\mathrm{M}$ and $\mathrm{Kra}, \mathrm{R} \mathrm{S}$, eds, Internatl ${ }^{14} \mathrm{C}$ conf, 12 th, Proc: Radiocarbon, v 28 , no. $2 \mathrm{~B}, \mathrm{p}$
$1022-1030$.

Valladas, G and Valladas, H, 1983, A variant of the thermoluminescence technique for beta-ray dosimetry: PACT, v 6, p 73-76. Zimmerman, D W, 1971, Thermoluminescent dating using fine grains from pottery:
Archaeometry, v 13, p 29-52. 